\title{
Paleomagnetism of the western Cape Fold belt, South Africa, and its bearing on the Paleozoic apparent polar wander path for Gondwana
}

\author{
Valerian Bachtadse ${ }^{1, *}$, Rob Van der Voo ${ }^{1}$ and Ingo W. Hälbich ${ }^{2}$ \\ 'Department of Geological Sciences, University of Michigan, Ann Arbor, MI 48109-1063 (U.S.A.) \\ ${ }^{2}$ Department of Geology, University of Stellenbosch, Stellenbosch, 7600 (South Africa)
}

Received January 30, 1987; revised version received May 7, 1987

\begin{abstract}
In order to test two different proposals for the poorly defined African Paleozoic apparent polar wander path (APWP), a paleomagnetic study was carried out on Ordovician through Carboniferous clastic sediments from the Cape Fold belt, west of the 22nd meridian. One proposal involves a relatively simple APWP connecting the Ordovician Gondwana poles in North Africa with the Late Paleozoic poles to the east of South Africa in a more or less straight line crossing the present equator in the Devonian. The other proposal adds a loop to this path, connecting Ordovician poles in North Africa with poles to the southwest of South Africa and then returning to central Africa. This loop would occur mainly in Silurian time. New results reported herein yield paleopoles in northern and central Africa for Ordovician to lowermost Silurian and Lower to Middle Devonian formations. The best determined paleopole of our study is for the Early Ordovician Graafwater Formation and falls at $28^{\circ} \mathrm{N}, 14^{\circ} \mathrm{E}\left(k=25, \alpha_{95}=8.8^{\circ}, N=28\right.$ samples $)$. The other paleopoles are not based on sufficient numbers of samples, but can help to constrain the apparent polar wander path for Gondwana. Our results give only paleopoles well to the north of South Africa and we observe no directions within the proposed loop. Hence, if the loop is real, it must have been of relatively short duration (60-70 Ma) and be essentially of Silurian/Early Devonian age, implying very high drift velocities for Gondwana (with respect to the pole) during that interval.
\end{abstract}

\section{Introduction}

Because the paleomagnetic data base for the Paleozoic of Gondwana is relatively poor, many uncertainties exist about the plate motions and paleogeographic positions of this supercontinent. As a consequence, models for Paleozoic continentcontinent collisions involving the present CircumAtlantic continents are very poorly constrained. The reasons for the paucity of data are manifold, and include a scarcity in general of Paleozoic rocks in the cratonic parts of the Gondwana continents, more particularly a lack of formations suitable for paleomagnetic analysis, a lack of precise ages for the rocks that do exist, the possibility of widespread remagnetization, and uncertainties about the positions of non-cratonic areas, such as the eastern Australian fold belts, which have yielded several paleomagnetic results previously.

* Now at: Department of Earth Sciences, University of Oxford, Parks Road, Oxford, OX1 3PR, United Kingdom.
Excluding earlier poles based on incomplete demagnetization analysis as well as results from possibly displaced terranes [1], there are essentially no reliable published poles for the $100 \mathrm{Ma}$ interval between the Late Ordovician and the Late Devonian: the only paleomagnetically acceptable pole is for the Mereenie Sandstone [2] but it is very poorly dated. Even the Middle to Late Devonian apparent polar wander path (APWP) segment for Gondwana is ambiguous, with a previously acceptable result for the Msissi Norite in Morocco [3] now discarded [4], and a result from Devonian rocks of the Gneiguira Supergroup arguably based on late Paleozoic remagnetizations [5-7]. Upper Devonian carbonates from the intracratonic Canning Basin in northwestern Australia have yielded a pole in African coordinates (on the basis of the Smith and Hallam [8] reconstruction) near to the equator in central Africa, which appears to give the best estimate for the Late Devonian paleofield of Gondwana thus far [7]. 

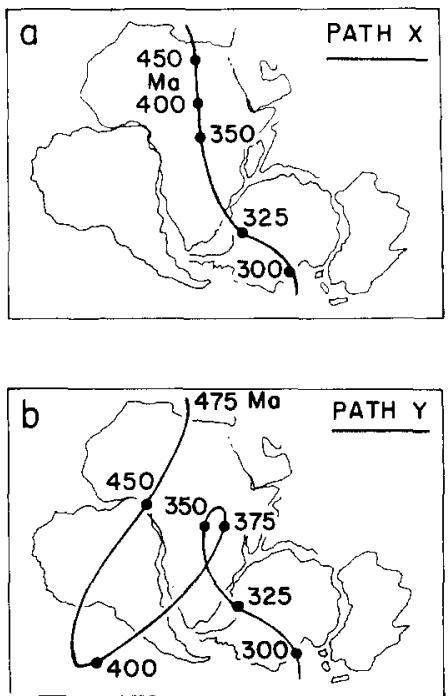

Fig. 1. Alternative Paleozoic apparent polar wander paths for Gondwana from [12]. (a) Path $X$ connecting the Early Paleozoic poles in northern Africa in a more or less straight line with the Carboniferous and younger poles. (b) Path $Y$, showing a loop in the Ordovician through Late Devonian interval, superimposed on path $X$. Ages are indicated in Ma.

It is not surprising, therefore, that mutually conflicting APWP's have been proposed for the southern continents on the basis of paleomagnetic data [1,9-12], or on the basis of glacial relicts [13]. Two models constitute the extremes among the different possibilities. One path connects the Ordovician paleopoles in northern Africa in a direct line southward through the continent with the Late Paleozoic poles just to the east of southern Africa (Fig. 1a); the other, based on glacial occurrences and paleomagnetic results from the East Australian fold belt, adds a south-southwest looping hairpin as an additional complexity of the path (Fig. 1b). These two models have been labeled path $X$ and path $Y$, respectively, by Morel and Irving [12]. Ring complexes in Niger, which give an Early Silurian age, have provided results in support of path $Y$, with pole positions to the west and southwest of southern Africa [14].

We report here paleomagnetic results from a very thick series of Paleozoic clastics in South Africa, comprising the Table Mountain, Bokkeveld and Witteberg Groups. Because ages span the interval from Ordovician to Carboniferous, it was hoped that paleopoles derived from the formations in these groups might shed further light on the African APWP, and hence the paleogeographic positions of Gondwana during this time.

\section{Geologic setting and sampling}

Clastic sedimentary rocks of the Cape Supergroup (7-9 km in thickness) unconformably overlie Precambrian/Cambrian metasediments and granitic rocks with ages as young as $530 \mathrm{Ma}$ [15], and are overlain by the Carboniferous Dwyka Formation of the Karroo sequence. The Cape Supergroup consists of the Table Mountain, the Bokkeveld and the Witteberg Groups. A schematic stratigraphic column is presented in Fig. 2, and a geological map with sampling sites is shown in Fig. 3. Folding is thought to be mostly of Triassic age $[17,18]$ and fold axes are mainly parallel to the present-day coastline of South Africa (Fig. 3). Deformation was most intense in the eastern Cape Province leading to penetrative cleavage [19], whereas the rocks in the western syntax area (Fig. 3), where we sampled, have been folded to a somewhat lesser degree.

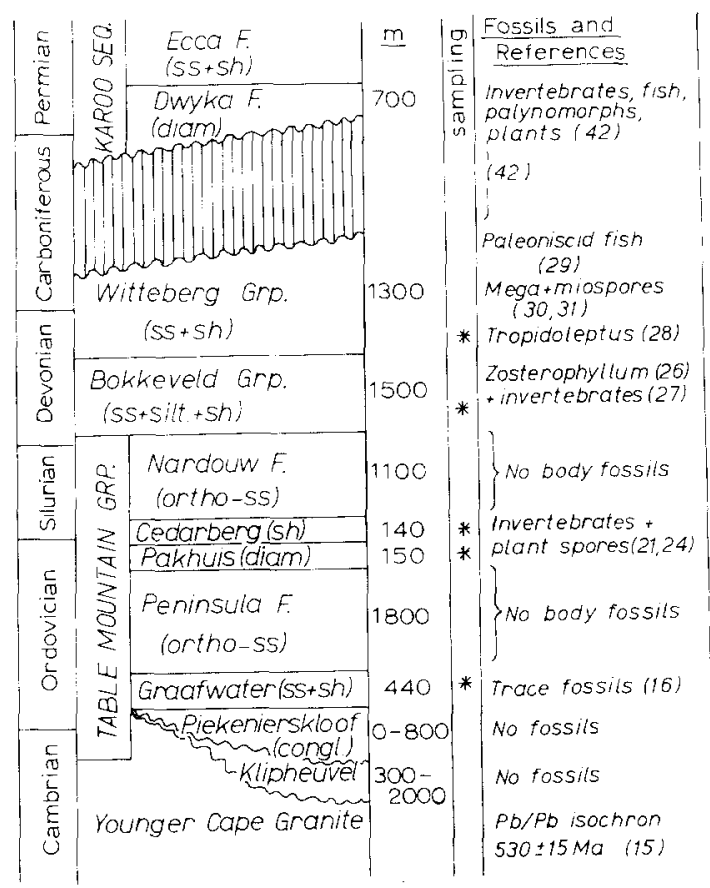

Fig. 2. Stratigraphic column of the Paleozoic formations in South Africa, with sampling marked for those formations discussed in this paper. The right-hand column gives diagnostic fossil occurrences and the references for these. 


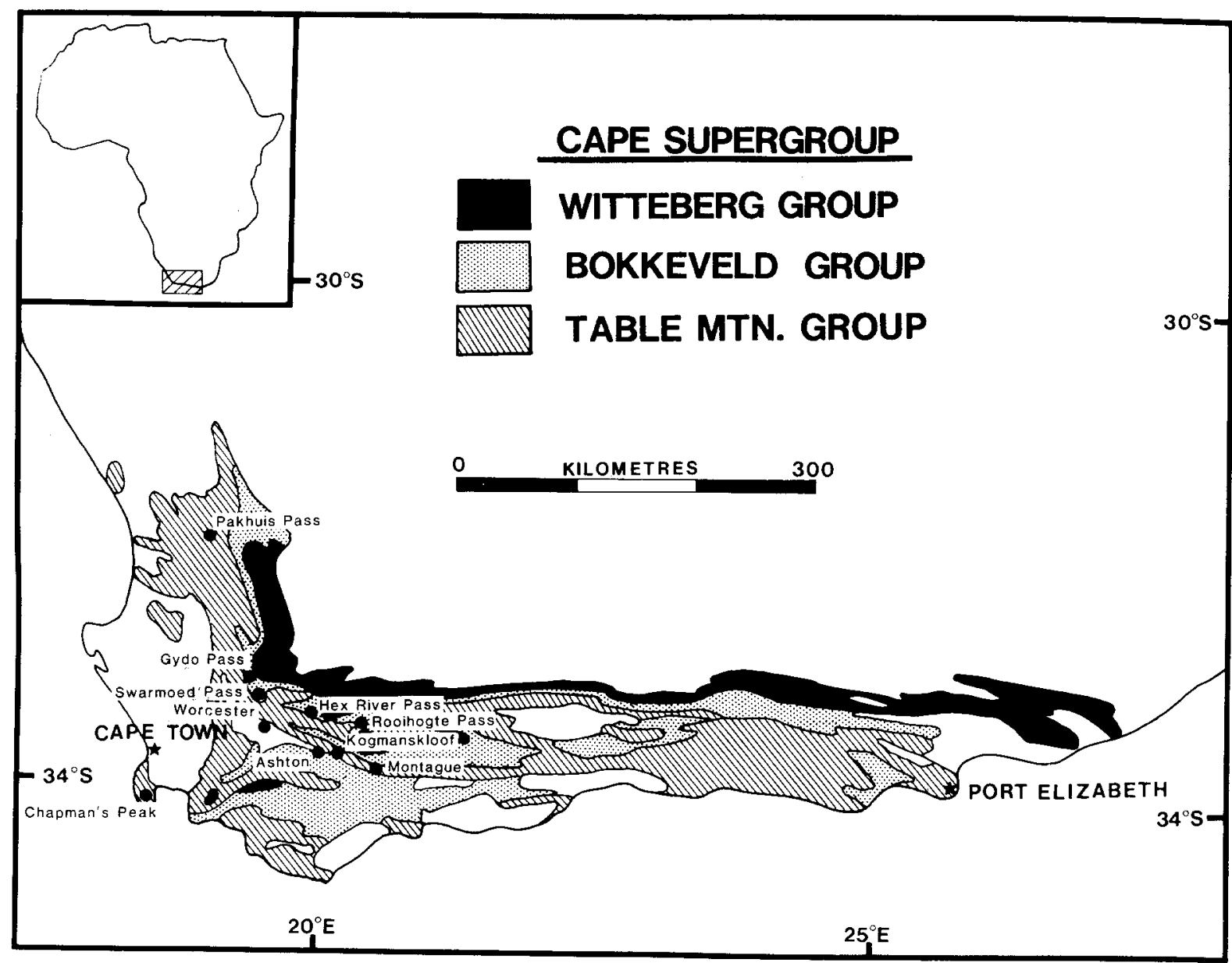

Fig. 3. Schematic geological map with sampling sites (dots) indicated.

Tankard and Hobday [20] interpreted the depositional environment of the Table Mountain, Bokkeveld and Witteberg Groups as typical for a basin that evolved as the failed arm of a major rift system, with more or less continuous Paleozoic subsidence leading to the immense thickness of at least $7000 \mathrm{~m}$ in a miogeosynclinal setting. Rock types include prominent quartz-arenites, conglomerates, diamictites and mudstones, as well as shales. While they are locally hematite bearing, such generally coarse rock types do not usually provide good paleomagnetic data and the finergrained strata have been preferred for sampling. Even so, we have encountered highly unstable magnetic behaviour in many of the formations sampled, and only four formations gave magnetizations of presumably Paleozoic age (the Graafwater, Pakhuis, Cedarberg Shale Formations and the Bokkeveld Group; see Fig. 2). Below, geological descriptions are given for these four formations only.

The Graafwater Formation is the third oldest in the Table Mountain Group. It was sampled along Chapman's Peak Drive, south of Cape Town (Fig. 3). Trace fossils indicate an Early Ordovician age [16], but the age is really only firmly bracketed by the basement (530 $\mathrm{Ma}$ or older) and the overlying well-dated Upper Ordovician formations. The rocks are red sediments of varying grain size, which were sampled at 12 stratigraphically distributed sites, with minor tilt of the strata only.

The Pakhuis Formation consists of gray massive diamictite, varying in thickness from 2 to $150 \mathrm{~m}$ [21], which is related to the Winterhoek glaciation $[15,22]$ that also affected the overlying Cedarberg Shale Formation [13]. These and coeval glacial 
deposits elsewhere in Africa and South America indicate that the center of the ice sheets was located in northwestern Africa and adjacent Brazil $[13,23]$. The Pakhuis Formation is well dated on the basis of brachiopods, trilobites and Chitinozoans as Upper Ordovician [24]. Fresh outcrops are rare, but 2 suitable sites were located at the type locality at Pakhuis Pass along the road between Clanwilliam and Wuppertal (Fig. 3); there the rocks are unweathered and occur as locally crossbedded, light-gray sandstones with thin lenses of quartz pebbles.

The Cedarberg Shale Formation consists of gray silty sandstone and finegrained carbonaceous shale, which carries isolated sand grains ascribed to ice-rafting [13]. The formation has yielded brachiopods, bryozoans, crinoids and a trilobite fauna of Late Ordovician [24] or perhaps Early Silurian age [25]. One site was sampled in nearvertical strata in the Kogmanskloof along the road from Ashton to Montagu.

The Bokkeveld Group, some $1500 \mathrm{~m}$ in thickness, consists of a series of five to six superimposed upward-coarsening marine sequences [16]. A hiatus spanning most of the Silurian has been inferred as separating this group from the underlying Nardouw Formation of the Table Mountain Group [13], but field evidence is lacking for such a gap (Theron and Oelofse, personal communication 1986). The occurrence of the plant Zosterophyllum [26] at $1400 \mathrm{~m}$ above the base of the formation and invertebrates [27] indicate a Lower to Middle Devonian age (see Fig. 2). It seems likely, therefore, that the Bokkeveld extends downward to the base of the Devonian or even into the Late Silurian. The deposition of the Nardouw sandstones would readily fill the presumed gap between the lowermost and the uppermost Silurian. The overlying Witteberg Group has yielded Givetian and younger Devonian as well as Carboniferous fossils [28-31], thus further constraining the upper age limit of the Bokkeveld. Sampling was carried out at 17 shallowly dipping sites at Gydo Pass, Swaarmoed, Rooihoogte Pass, Hex River Pass, and near Worcester and Montague, with lithologies ranging from black shales to brown and red sandstones. Only the brown sandstones from Gydo Pass gave stable ancient magnetizations.

All samples were drilled in the field with a gasoline-powered portable drill and oriented with a standard Brunton compass, with a correction for the local geomagnetic declination.

\section{Laboratory techniques}

The oriented cores of $2.5 \mathrm{~cm}$ diameter were cut to $2.14 \mathrm{~cm}$ length and the uppermost more weathered portions of the cores were discarded. Samples were stored in a magnetically shielded room with a residual field of less than $200 \mathrm{nT}$, in order to reduce viscous magnetic effects. Natural remanent magnetizations (NRM's) were measured with a ScT cryogenic magnetometer and stepwise alternating field (AF) and thermal demagnetizations were performed in field-free space (residual fields less than $5 \mathrm{nT}$ ) with Schonstedt equipment.

Demagnetization data were plotted in orthogonal diagrams [32] and on stereographic projections for great-circle analysis [33]. Principal component analysis [34] has been applied; results with mean angular deviations (MAD) greater than $15^{\circ}$, or based on fewer than 4 consecutive measurements, were not used.

\section{Paleomagnetic results}

NRM intensities generally ranged from $10^{-5}$ to $10^{1} \mathrm{~A} / \mathrm{m}$. Directions of NRM before any demagnetization treatment were typically highly scattered indicating unstable or multivectorial nature of the remanence. Indeed, many samples showed unstable behavior during demagnetization, which resulted in uninterpretable orthogonal vector plots. Examples of such behavior are not very illuminating, but are shown here to illustrate the reasons for discarding such samples (Fig. 4). In essence, when results from a collection of samples such as ours are discussed, we feel that it is important to document that the directions reported represent all the information contained in the orthogonal plots and that no possibly meaningful results go unreported. In the case of the discarded results, no information about ancient (or recent) magnetizations was revealed by the demagnetizations above minimally acceptable levels of coercivity or blocking temperature, as can be readily seen in Fig. 4.

Before discussing the results from the individual formations that did show stable magnetic be- 

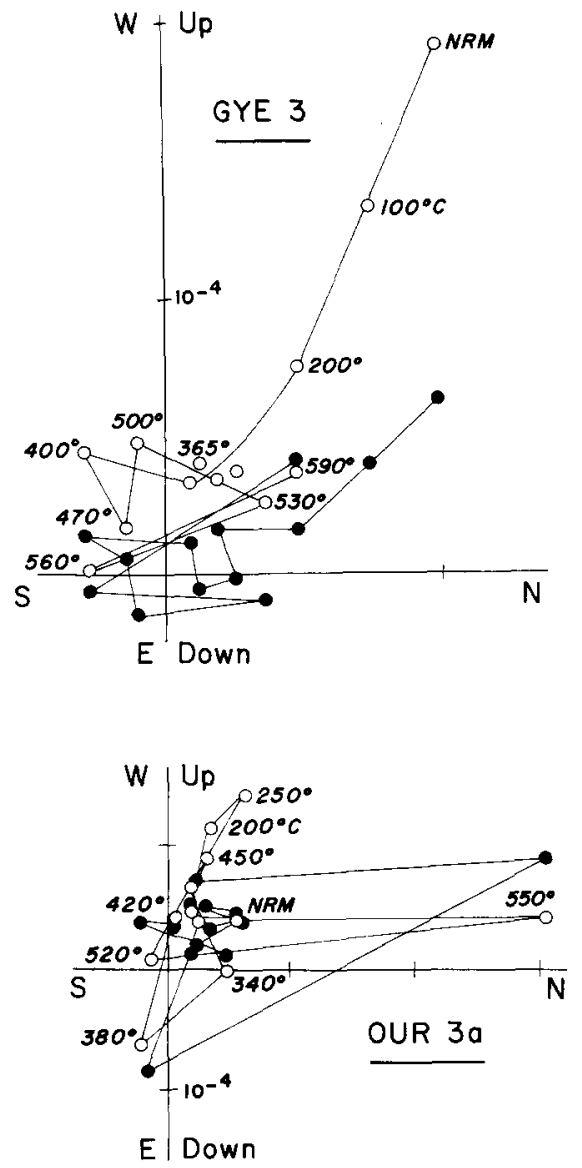

Fig. 4. Orthogonal vector demagnetization diagrams [32] representative of the large majority of samples which show mainly unstable remanence. Full (open) symbols represent projections onto the horizontal (vertical) plane. Labels on the axes represent intensities in $\mathrm{A} / \mathrm{m}$. Samples are from the Bokkeveld Group (top) and the Graafwater Formation (bottom). havior during demagnetization, we point out that these results can generally be grouped into three categories. These are:

(1) group one comprises results which show a direction of magnetization that conforms to the present-day geomagnetic field direction (pdf), or its antipodal direction. Such directions may fail the fold test [35] and are likely to be of Recent or Late Tertiary origin.

(2) Group two comprises magnetizations which have coherence at the site or formation level and appear to be ancient in that they are significantly different from the pdf.

(3) Group three comprises results which do not show coherence at the site or formation level, despite apparently colinear vector plot segments. It was found that these results could be interpreted with great-circle techniques as being based on overlapping coercivity or blocking temperature spectra of more than one stable component of magnetization.

Table 1 lists the formations for which stable magnetizations could be obtained, with separate columns indicating the numbers of samples that fall into these three categories, as well as the number of unstable samples. The total number of samples thus reported on comprises the total number of samples analyzed. While it is unfortunate that only small percentages of our collections gave ancient (i.e., Paleozoic) magnetizations, we feel reasonably confident that no other paleomagnetic information can possibly be obtained from these rocks.

Presumably Paleozoic magnetizations were ob-

TABLE 1

Summary of paleomagnetic directions obtained in this study

\begin{tabular}{|c|c|c|c|c|c|c|c|c|c|c|c|}
\hline Rock unit & $\begin{array}{l}\text { Total } \\
N\end{array}$ & $\begin{array}{l}\text { Unstable } \\
N_{1}\end{array}$ & $\begin{array}{l}\text { Pdf } \\
N_{2} \\
\end{array}$ & $\begin{array}{l}\text { Composite } \\
N_{3}\end{array}$ & $\begin{array}{l}\text { Characteristic } \\
N_{4} \text { (sites) }\end{array}$ & $\begin{array}{l}\text { Decl/Incl } \\
\text { before TC }\end{array}$ & $k$ & $\alpha_{95}$ & $\begin{array}{l}\mathrm{Decl} / \text { Incl } \\
\text { after TC }\end{array}$ & $k$ & $\alpha_{95}$ \\
\hline \multicolumn{12}{|c|}{ Characteristic directions } \\
\hline Graafwater ${ }^{a}$ & 63 & 25 & 0 & 10 & $28(12)$ & $176 /-47$ & 28 & 8 & $174 /-47$ & 25 & 9 \\
\hline \multicolumn{12}{|l|}{ Pakhuis / } \\
\hline Cedarberg & 33 & 18 & 6 & 0 & $9(2+1)$ & $141 /-40$ & 6 & 23 & $145 /-37$ & 9 & 18 \\
\hline Bokkeveld & 119 & 87 & 16 & 3 & $13(1)$ & $349 /+60$ & 55 & 6 & $354 /+64$ & 33 & 7 \\
\hline \multicolumn{12}{|c|}{ Remagnetized directions } \\
\hline Witteberg & 134 & 91 & 27 & 3 & $13(1)$ & $359 /-58$ & 35 & 5 & $353 /-48$ & 8 & 10 \\
\hline
\end{tabular}

a Mean directions on the basis of the twelve site means given in Table 2. The other mean directions are based on sample directions. $N$ is the number of samples; Decl/Incl is declination and inclination in degrees; TC is the correction for the tilt of the strata; $k$ and $\alpha_{95}$ are the statistical parameters associated with the mean [38]. 


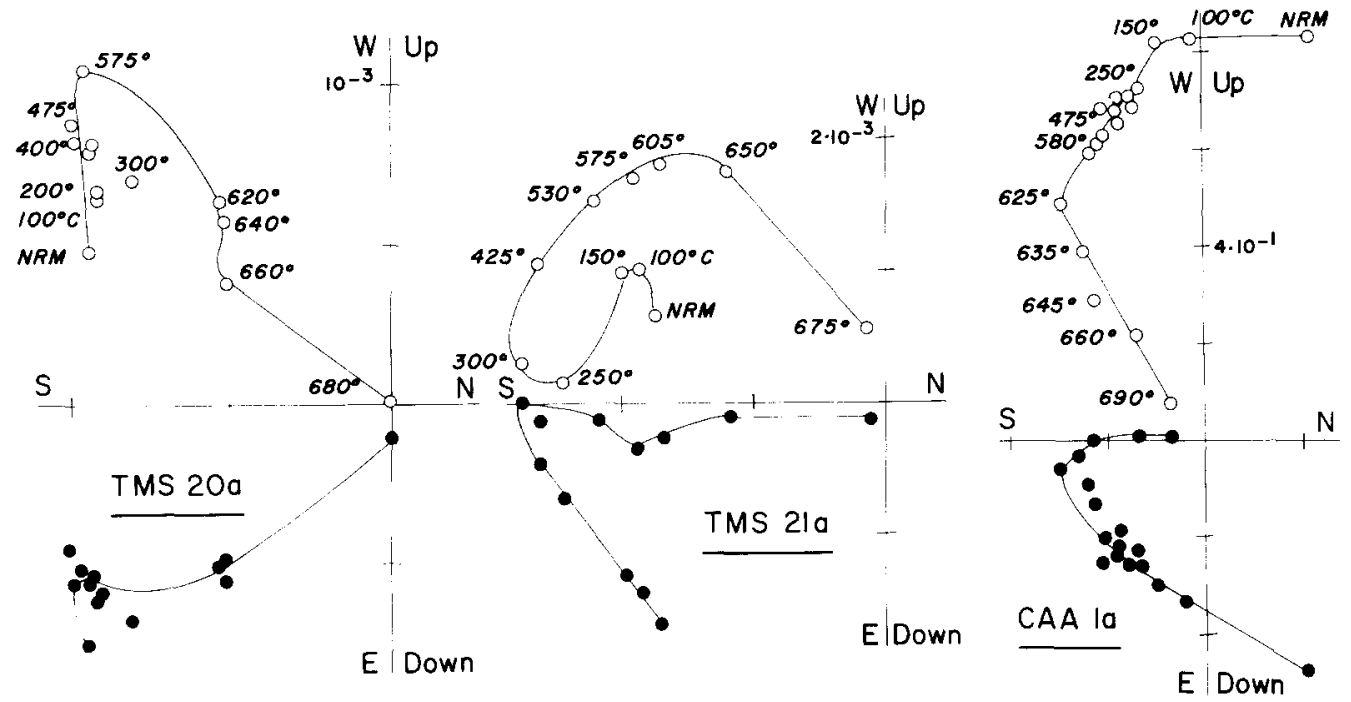

Fig. 5. Orthogonal demagnetization diagrams (as in Fig. 4) showing characteristic directions of magnetization at high temperatures for samples from the Early Ordovician Graafwater Formation.

tained from four formations (the Graafwater, Pakhuis, Cedarberg Shale Formations and Bokkeveld Group). In addition, the Witteberg group gave post-folding directions of Late Tertiary to recent origin. The results from these units are described individually below.

\subsection{The Early Ordovician Graafwater Forma- tion \\ NRM directions were poorly grouped, but showed a predominance of shallow easterly to}

southerly magnetizations, quite similar to previous paleomagnetic results reported by Graham [36], who did not perform demagnetizations.

Thermal demagnetization proved to be most effective in treating these red bed samples, and blocking temperatures predictably ranged up to over $670^{\circ} \mathrm{C}$. Examples of thermal demagnetization plots are given in Fig. 5; at temperatures above $625^{\circ} \mathrm{C}$ these and many other samples showed a somewhat noisy decay toward the origin of the coordinate system after removal of lower-

\section{TABLE 2}

Site-means for the Graafwater Formation

\begin{tabular}{|c|c|c|c|c|c|c|c|}
\hline Site No. & $N$ & $\begin{array}{l}\mathrm{Decl} / \mathrm{Incl} \\
\text { before TC }\end{array}$ & $k$ & $\alpha_{95}$ & $\begin{array}{l}\mathrm{Decl} / \text { Incl } \\
\text { after TC }\end{array}$ & $k$ & $\alpha_{95}$ \\
\hline CAA & 3 & $166 /-57$ & 190 & 9 & $167 /-61$ & 214 & 8 \\
\hline $\mathrm{CAC}$ & 2 & $143 /-49$ & - & - & $143 /-49$ & - & - \\
\hline $\mathrm{CAG}$ & 3 & $162 /-43$ & 50 & 13 & $162 /-43$ & 50 & 13 \\
\hline $\mathrm{CAH}$ & 1 & $192 /-31$ & - & - & $192 /-31$ & - & - \\
\hline TSM 1 & 2 & $200 /-51$ & - & - & $200 /-57$ & - & - \\
\hline TSM 2 & 3 & $173 /-49$ & 8 & 46 & $170 /-53$ & 8 & 46 \\
\hline TSM 3 & 2 & $181 /-30$ & - & - & $180 /-27$ & - & - \\
\hline TSM 4 & 3 & $166 /-50$ & 3 & 31 & $163 /-48$ & 3 & 31 \\
\hline TSM 5 & 2 & $162 /-46$ & - & - & $160 /-42$ & - & - \\
\hline TSM 6 & 3 & $159 /-44$ & 23 & 27 & $159 /-44$ & 23 & 28 \\
\hline TSM 7 & 3 & $18 /+49$ & 32 & 22 & $5 /+46$ & 32 & 22 \\
\hline TSM 8 & 1 & $205 /-45$ & - & - & $198 /-42$ & - & - \\
\hline
\end{tabular}

For explanation of abbreviations see Table 1. 


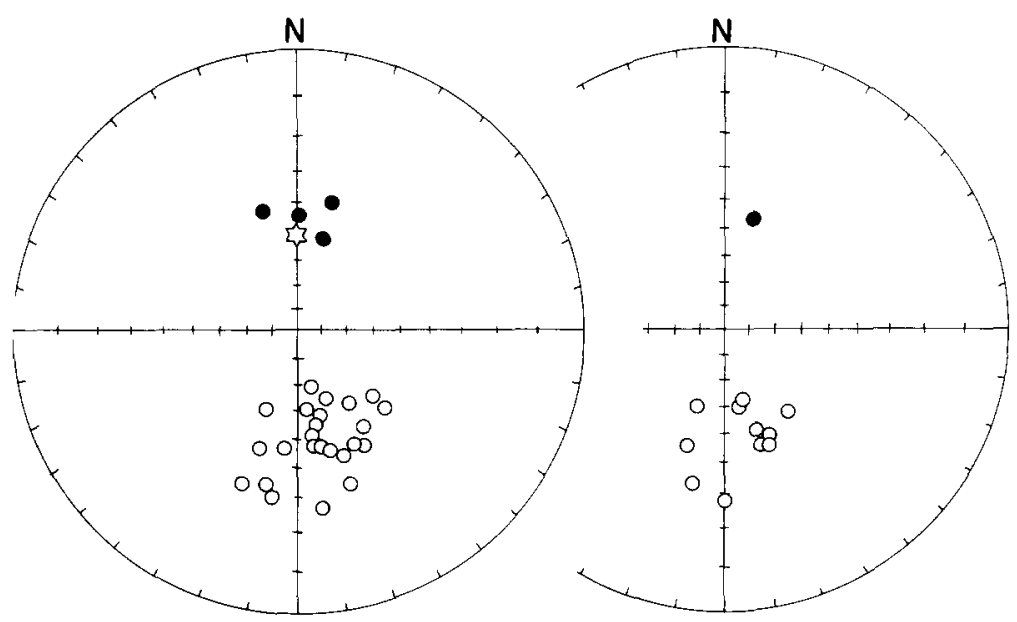

Fig. 6. Equal-angle stereonet projection of the characteristic directions of the Graafwater Formation for individual samples (left) and the site means (right) after correction for the (minor) tilt of the strata. Closed (open) symbols on the lower (upper) hemisphere. The open star represents the present-day dipole field direction.

temperature overprints. The high-temperature directions are here called the characteristic directions for the Graafwater Formation; a total of 28 samples from 12 sites show this characteristic direction (Table 2), which is generally to the south and upward, although four samples from two sites showed antipodal northerly and downward directions (Fig. 6). The pdf direction (northerly and upward, as shown by the open star in Fig. 6) is quite different from the observed characteristic directions, but is recognized in many samples in the lower blocking-temperature overprints.

Several samples, however, showed colinear trajectories during thermal demagnetization, which clearly bypassed the origin (Fig. 7). The directions of these trajectories did not show any coherence at the site or formation level and were analyzed by the great-circle technique of Halls [33]. The remagnetization circles thus obtained from the apparently colinear segments (generally above
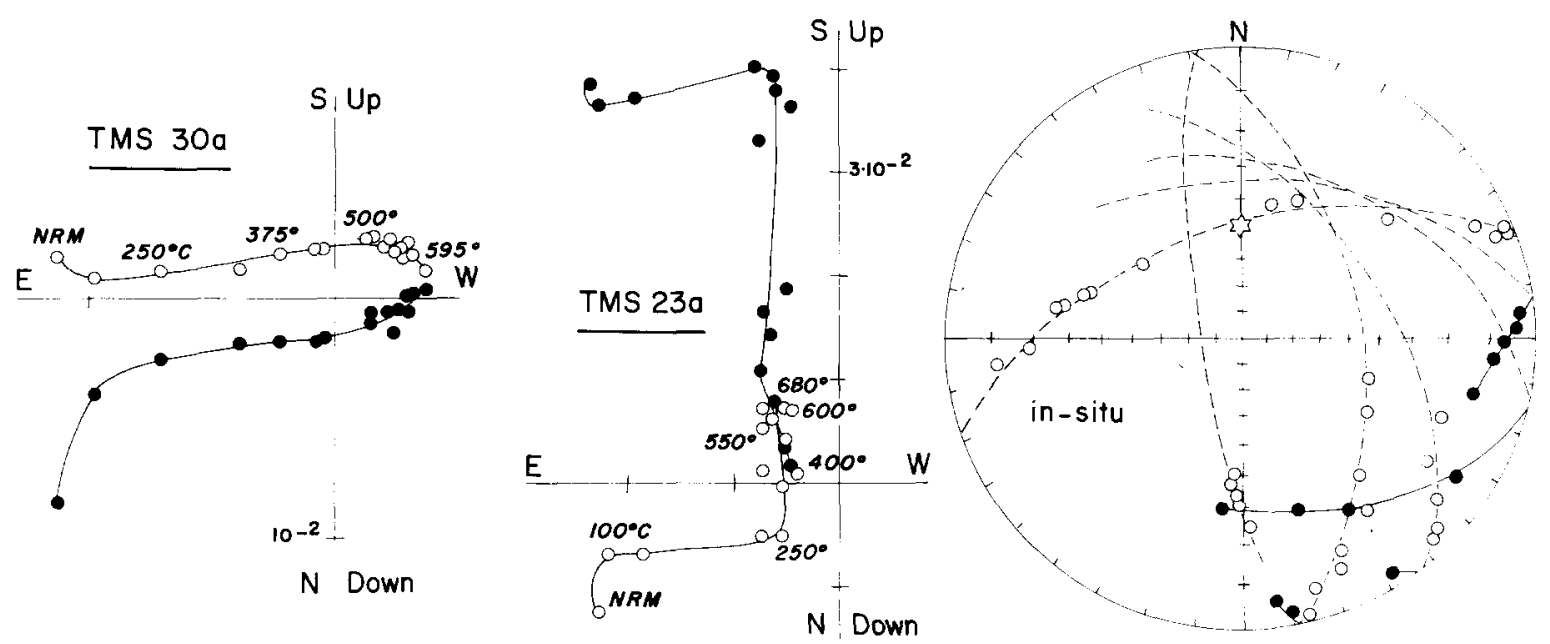

Fig. 7. Orthogonal demagnetization diagrams (as in Fig. 4) showing multivectorial (composite) remanence in samples from the Graafwater Formation, which cannot be uniquely resolved from the plots; on the right, great-circles are shown for several such samples in equal-angle projection. These only show an intersection at the northerly and upward present-day field direction (open star). Solid lines and symbols are lower-hemisphere projections; dashed lines and open symbols are upper-hemisphere projections. 


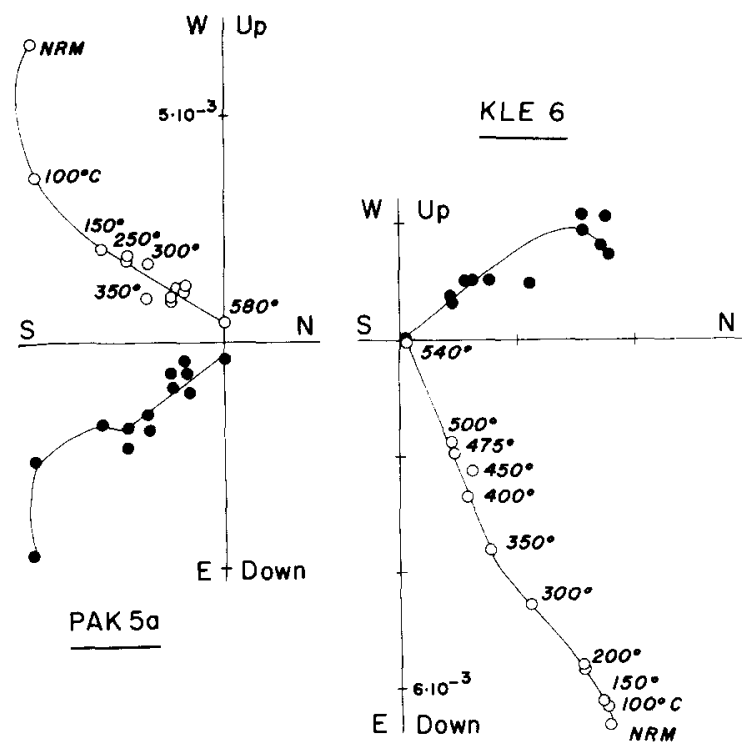

Fig. 8. Orthogonal demagnetization diagrams (as in Fig. 4) for samples from the Upper Ordovician Pakhuis Formation.

$150^{\circ} \mathrm{C}$ ) are also shown in Fig. 7 ; they converge at a northerly and upward direction, and we conclude that the samples that revealed this composite multivectorial behavior contained a large component of magnetization that conforms to the pdf direction (star in Fig. 7). No other great-circle intersection is apparent in these samples, since the correction for the tilt of the strata is only minor. Thus, no other directions of magnetization could be obtained from this subset of samples. We note that the undemagnetized NRM directions of Graham [36], which resulted in a paleopole that is often used in the literature (pole 4-9 of [37]), are likely to have been based on such composite behavior and that this pole should no longer be used for paleomagnetic purposes.

\subsection{The Late Ordovician to earliest Silurian Pakhuis and Cedarberg Shale Formations}

Thermal demagnetization behavior is illustrated in the vector plots of Fig. 8. Maximum unblocking temperatures no higher than $580^{\circ} \mathrm{C}$, and generally linear decay to the origin after removal of an insignificant low-blocking temperature component, characterized the stable samples of these formations. It is likely that magnetite is the main magnetic carrier in these gray silty sandstones. Both northwesterly downward and southeasterly upward directions were observed (Figs. 8,9) in a total of 9 samples from 3 sites. Although the directions cluster only moderately well, correction for the tilt of the strata results in an increase in the clustering of the directions and in an increase in the precision parameter $k$ [38] from 6 to 9. This slight improvement may be taken as a suggestion that these magnetizations are of pre-Triassic age, but it is not statistically significant.

\subsection{The Early to Middle Devonian Bokkeveld} Group

Only the brown sandstones (one site) of this unit, sampled at Gydo Pass, gave stable magnetic

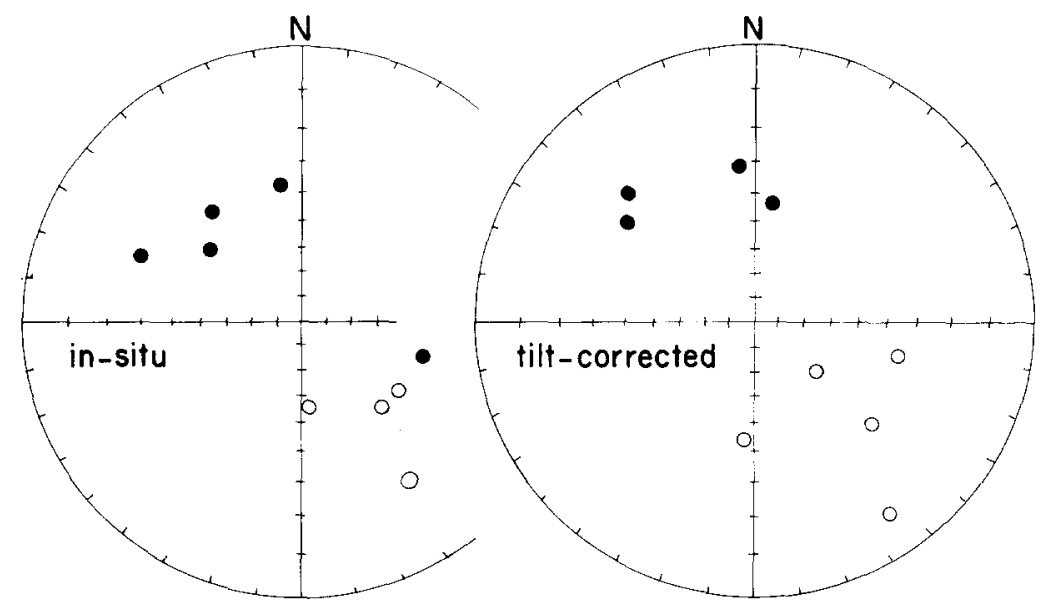

Fig. 9. Characteristic directions (as in Fig. 6) of the Pakhuis and Cedarberg Shale formations for individual samples before (left) and after (right) correction for the tilt of the strata. 


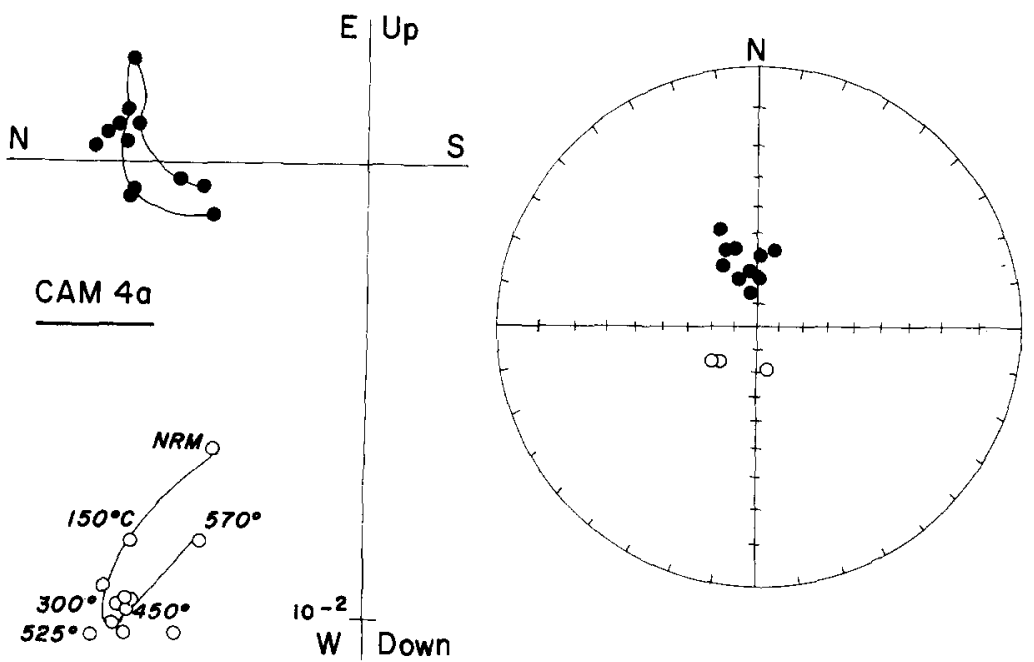

Fig. 10. Orthogonal demagnetization diagram (as in Fig. 4) for a sample from the Lower to Middle Devonian Bokkeveld Formation collected at Gydo Pass (left) and equal-angle stereonet (as in Fig. 6) showing all characteristic directions obtained from the samples of this formation, after correction for the (minor) tilt of the strata.
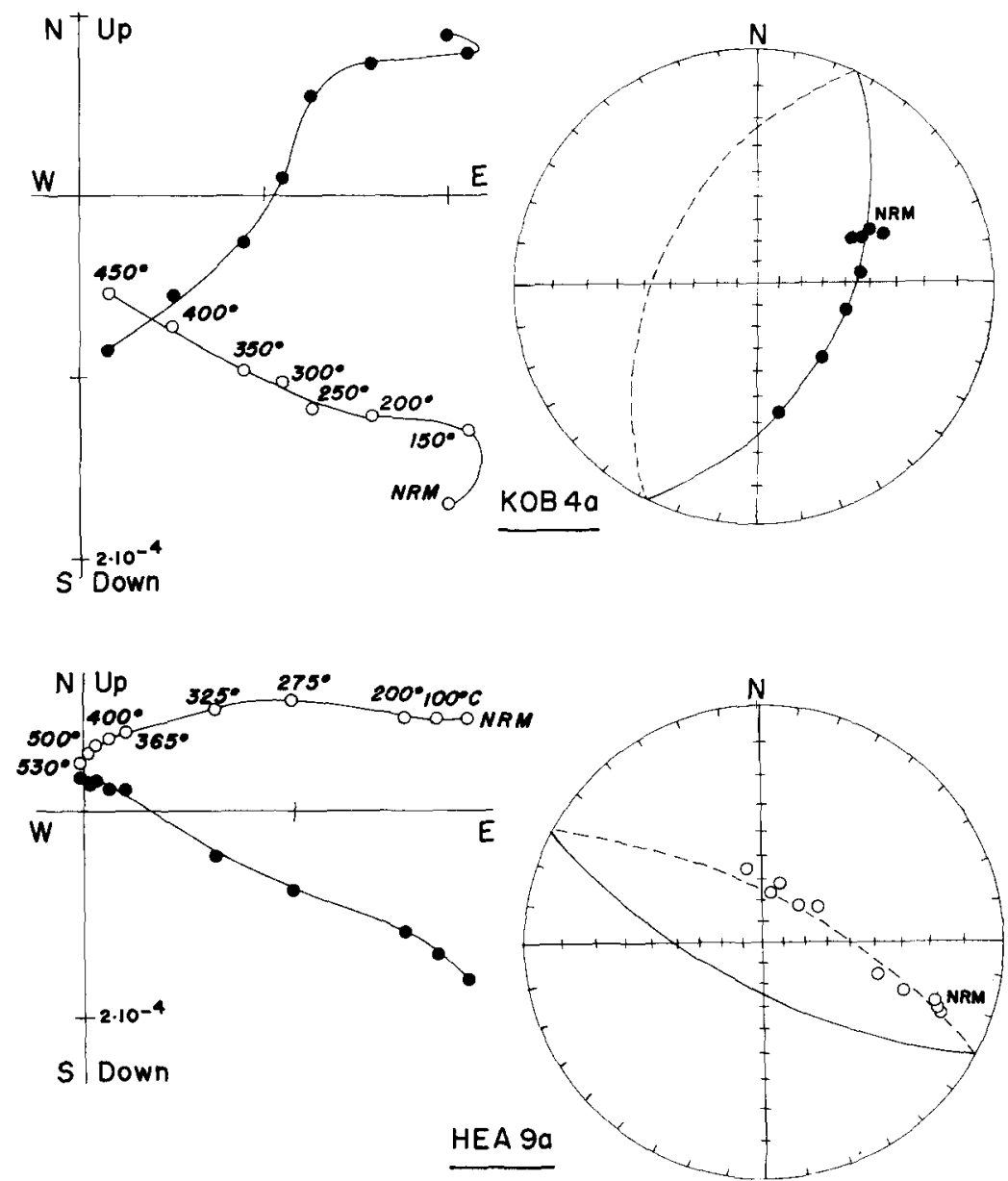

Fig. 11. Orthogonal demagnetization diagrams for samples from the Bokkeveld Formation showing composite multivectorial remanence (left) and corresponding great circles (right), which intersect at a northerly and upward present-day field direction. Conventions as in Fig. 7. 

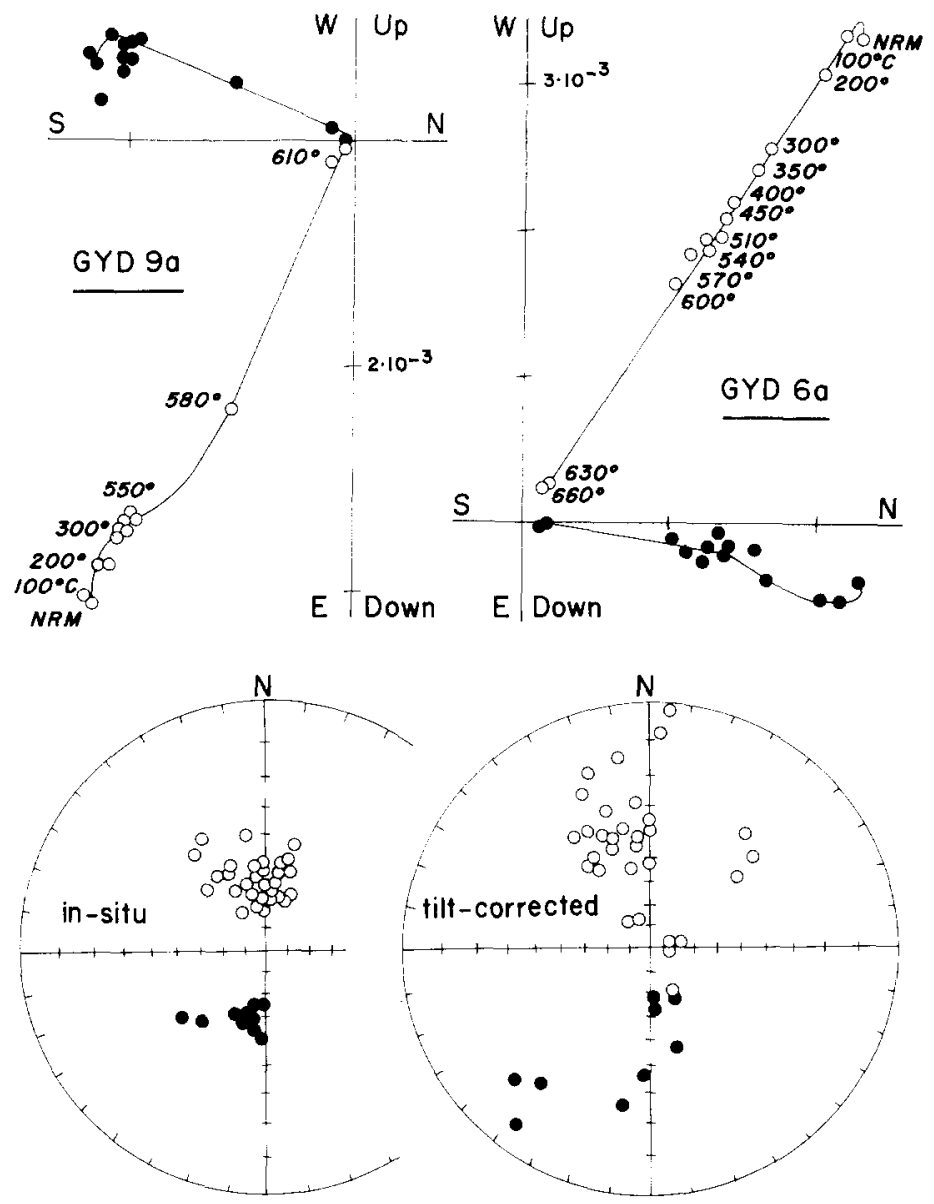

Fig. 12. Orthogonal demagnetization diagrams (top) for samples from the Bokkeveld and Witteberg formations, which show only the present-day field or its antipodal (southerly and down) direction. Conventions as in Fig. 4. The bottom stereonets (as in Fig. 6) show these remagnetization directions before and after correction for the tilt of the strata, illustrating the negative fold test.

results which were different from the pdf. Uniformly high blocking temperatures above $580^{\circ} \mathrm{C}$ are indicative of hematite. However, mineralogical changes occurred in almost all samples during heating which caused magnetic instability above $580^{\circ} \mathrm{C}$. Thus we cannot conclude that we have demonstrated the univectorial nature of the magnetizations remaining above $580^{\circ} \mathrm{C}$ (such as shown in Fig. 10), although it is likely that at this temperature the characteristic magnetization has been isolated, i.e., if any overprints or secondary magnetization exist in these samples they appear to have been eliminated by this temperature. The stable end-point directions thus obtained are also shown in Fig. 10; they are predominantly to the north and downward, although three samples have antipodal directions. Corrections for the tilt of the strata do not result in a significant fold test, because only one site was sampled, albeit with slightly variable bedding attitudes.

As was the case with the Graafwater Formation, some samples (three) showed curved demagnetization trajectories which bypassed the origin, suggesting a multivectorial remanence. Orthogonal vector plots and stereonets with greatcircle trajectories are shown in Fig. 11. The trajectories intersect at a northerly and upward direction close to the pdf, and again we conclude that the only direction that can be obtained from this subset of samples is likely to be of recent origin.

The remaining samples of the Bokkeveld Group show mostly univectorial pdf directions, or inter- 
TABLE 3

Pole positions from this study

\begin{tabular}{lllrl}
\hline Formation & Decl/Incl & Paleopole & $d p$ & $d m$ \\
\hline Graafwater & $174 /-47$ & $28^{\circ} \mathrm{N}, 14^{\circ} \mathrm{E}$ & 7.5 & 11.7 \\
Pakhuis/Cedarberg & $145 /-37$ & $25^{\circ} \mathrm{N}, 343^{\circ} \mathrm{E}$ & 12.5 & 21.0 \\
Bokkeveld & $354 /+64$ & $10^{\circ} \mathrm{N}, 15^{\circ} \mathrm{E}$ & 8.9 & 11.1 \\
$\begin{array}{l}\text { Bokkeveld/Witteberg } \\
\text { secondary }\end{array}$ & $359 /-58$ & $85^{\circ} \mathrm{N}, 206^{\circ} \mathrm{E}$ & 5.5 & 7.3 \\
\hline
\end{tabular}

estingly, a direction antipodal to the pdf (Fig. 12). These magnetizations generally reside, at least for a large part, in hematite in unaltered black shales as well as in red sandstones. The next younger unit, the Witteberg Group, also reveals this remagnetization, as will be discussed below.

\subsection{The Witteberg Group}

All the (eleven) samples from this unit which behave stably during demagnetization revealed pdf directions, or its antipodal counterpart. When combined with similar directions from the Bokkeveld Group, these results fail a regional fold test, indicating that this magnetization is of postTriassic age (Fig. 12). The dual polarity observed for this remagnetization may explain the composite nature of some of the Graafwater and Bokkeveld units, which through great-circle analysis appeared to give only intersections near the present-day field, if it can be assumed that in the latter samples both normal and reversed polarity components are present. The dual-polarity result, furthermore, argues against a viscous acquisition of this remagnetization. Unlike some apparently Jurassic remagnetizations observed in Permotriassic sediments of South Africa and Botswana [39], the paleopole for the remagnetization discussed here is indistinguishable from that for the Late Tertiary and Quaternary (Table 3 ), arguing for a relatively recent rather than a Mesozoic age for this event.

\section{Discussion}

The behavior of the samples during demagnetization leads to a classification into four different groups: unstable magnetizations, present-day field or Late Tertiary remagnetizations, multivectorial remanence with overlapping blocking temperature spectra and, lastly, characteristic (presumably ancient) directions of magnetization. In Table 1 we identify the number of samples in each group. Of the four groups, the first two are paleomagnetically uninteresting, and not at all surprising given the coarse clastic nature of many of the samples, which in our experience rarely is suitable for paleomagnetic study.

The multivectorial remanence could be analyzed with great-circle techniques, but this resulted only in intersections near to the present-day field direction. These samples thus contain present-day remagnetizations as well as possibly ancient field directions, but no information could be retrieved about the latter. Thus about $80 \%$ of a total of 230 samples have not yielded any information about ancient directions.

The remaining 50 samples (about 20\% of the total), however, have yielded directions that were often of dual polarity, with northerly downward and southerly upward magnetizations. The nearest paleopoles, therefore, fall generally to the north of the South African sampling sites, and are located in Central Africa for the Bokkeveld Group and in northwest Afrfica or further to the northwest for the older Graafwater, Pakhuis and Cedarberg Shale formations (Table 3). Given the small numbers of samples involved for the Bokkeveld, Pakhuis and Cedarberg Shale, only the paleopole for the Graafwater meets modern reliability criteria, but the other paleopoles may nevertheless be useful to constrain our current thinking about the African APWP.

Before discussing this APWP, we have to address the question whether all the ancient magnetic directions observed are primary, i.e., whether they are of nearly the same age as the rocks. In the absence of stringent tests for the age of magnetization, only circumstantial evidence can be given in favor of our conclusion that the magnetizations were acquired early (soon after, or even during deposition of the sediments). The Carboniferous and younger segments of the African APWP are known with reasonable accuracy, and fall entirely to the east and south of our sampling sites [40]. The directions and paleopoles of Table 3 are therefore likely to be pre-Carboniferous. The Bokkeveld paleopole is located just to the north of the Late Devonian pole from western Australia [7] in a Smith and Hallam Gondwana reconstruction [8], 
which agrees well with the relative ages of these two results. The Pakhuis/Cedarberg Shale and Graafwater paleopoles fall near other Ordovician paleopoles for Gondwana [40] and are themselves different from any poles with younger (i.e., postEarly Silurian) ages. In view of these considerations there are no compelling reasons to treat the paleopoles as being based on remagnetization significantly later than the time of deposition.

Returning now to the issues raised in the Introduction about a possible mid-Paleozoic loop of the African APWP, which involves paleopoles just to the west or southwest of South Africa, we observe that our results do not support these poles (Fig. 13). This does not imply that the loop does not exist. However, for the ages covered by our results the pole seems to be generally located in northern or central Africa. Thus, we conclude that if the loop is real, and new results [14] suggest this to be true, then it must have occurred in the 60-70 Ma time-span between the latest Ordovician and the Middle Devonian.

While final corroboration and publication of the preliminary results are needed, we note that the occurrence of the loop, essentially in Silurian and Early Devonian time, requires high velocities with respect to the pole for Africa, of the order of $10-15 \mathrm{~cm} /$ year. Such velocities for large continental cratonic areas are unusual when compared with documented plate velocities for Phanerozoic time [41].

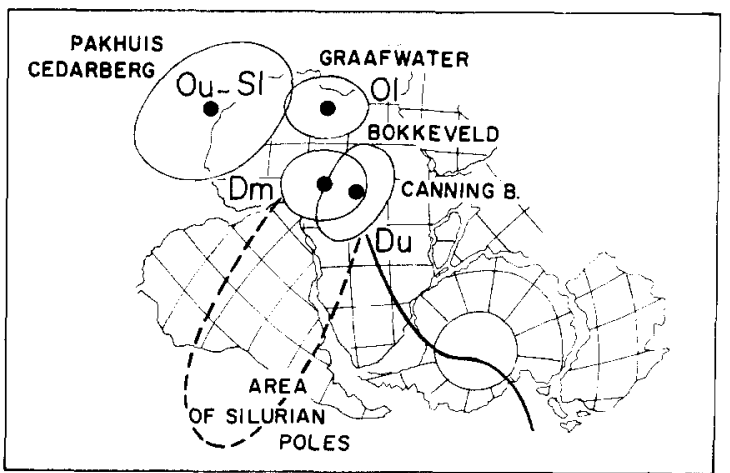

Fig. 13. Paleopoles obtained in this study (Graafwater, Pakhuis/Cedarberg and Bokkeveld) compared with the apparent polar wander path for Gondwana. The Late Devonian Canning Basin pole is for rocks from western Australia [7]. The area of Silurian paleopoles represents the general location of the site-mean poles from Niger [14]. The dashed segment is a possible pole path loop discussed in the text.

\section{Acknowledgements}

We thank Alfred Kröner for his initial sampling and his inspiration and Rob Hargraves, Dennis Kent, and G.S. Murthy for valuable comments on the manuscript. Martha M. Ballard collected additional samples. I.W. Hälbich would like to thank H. Theron and B. Oelofse for valuable discussions; Andre Van der Merwe is gratefully acknowledged for his help to V. Bachtadse while sampling in the field. This research was supported in part by the Scott Turner Fund of the University of Michigan and by the Division of Earth Sciences, the National Science Foundation, grant EAR 84-07007.

\section{References}

1 B.R. Goleby, Early Paleozoic paleomagnetism in South East Australia, J. Geomagn. Geoelectr. 32, Suppl. III, S11-21, 1980.

2 B.J.J. Embleton, The paleomagnetism of some Paleozoic sediments from central Australia, J. and Proc. R. Soc. N.S.W. 105, 86-93, 1972.

3 E.A. Hailwood, Paleomagnetism of the Msissi Norite (Morocco) and the Palaeozoic reconstitution of Gondwanaland, Earth Planet. Sci. Lett. 23, 376-386, 1974.

4 E. Salmon, R. Montigny, J.B. Edel, A. Pique, R. Thuizat and $M$. Westphal, The Msissi Norite revisited: $K / A r$ dating, petrography and paleomagnetism, Geophys. Res. Lett. 13, 741-743, 1986.

5 D.V. Kent, O. Dia and J.M.A. Sougy, Paleomagnetism of

* Lower-Middle Devonian and Upper ProterozoicCambrian (?) rocks from Mejeria (Mauritania, West Africa), Am. Geophys. Union, Geodyn. Ser. 12, 99-115, 1984.

6 P.W. Schmidt, B.J.J. Embleton, T.J. Cudahy and C.M. Powell, Prefolding and pre-megakinking magnetizations from the Devonian Comerong volcanics, New South Wales, Australia, and their bearing on the Gondwana pole path, Tectonics 5, 135-150, 1986.

7 N.F. Hurley and R. Van der Voo, Paleomagnetism of Late Devonian reefal limestones, Canning Basin, Western Australia, Geol. Soc. Am. Bull. 98, 138-146, 1987.

8 A.G. Smith and A. Hallam, The fit of the southern continents, Nature 225, 139-144, 1970.

9 M.W. McElhinny, Paleomagnetism and Plate Tectonics, 358 pp.. Cambridge University Press, Cambridge, 1973.

10 B.J.J. Embleton, M.W. McElhinny, A.R. Crawford and G.R. Luck, Paleomagnetism and the tectonic evolution of the Tasman orogenic zone, J. Geol. Soc. Aust. 21, 187-193, 1974.

11 P.W. Schmidt and W.A. Morris, An alternative view of the Gondwana Paleozoic apparent polar wander path, Can. J. Earth Sci. 14, 2674-2678, 1977.

12 P. Morel and E. Irving, Tentative paleocontinental maps for the Early Phanerozoic and Proterozoic, J. Geol. 86, $535-561,1978$. 
13 M.V. Caputo and J.C. Crowell, Migration of glacial centers across Gondwana during the Paleozoic Era, Geol. Soc. Am. Bull. 96, 1020-1036, 1985.

14 R.B. Hargraves, E.M. Dawson and F.B. Van Houten, Paleomagnetism and age of Mid Paleozoic ring complexes in Niger, West Africa, and tectonic implications, Geophys. J.R. Astron. Soc., in press, 1987.

15 F.E. Leygonie, Die graniete van Langebaan, K.P., Ann. Univ. Stellenbosch A1(2), 33-105, 1977.

16 A.J. Tankard, M.P.A. Jackson, K.A. Eriksson, D.K. Hobday, D.R. Hunter and W.E.L. Minter, Crustal Evolution of Southern Africa-3.8 Billion Years of Earth History, 523 pp., Springer Verlag, Heidelberg, 1982.

17 B.E. Lock, Flat-plate subduction and the Cape Fold belt of South Africa, Geology 8, 35-39, 1980.

18 I.W. Hälbich, A geodynamic model for the Cape Fold belt, in: Geodynamics of the Cape Fold Belt, A.P.G. Soehnge and I.W. Hälbich, eds., Spec. Publ. Geol. Soc. S. Afr. 12, 165-172, 1983.

19 I.W. Hälbich and D.H. Cornell, Metamorphic history of the Cape Fold Belt, in: Geodynamics of the Cape Fold Belt, A.P.G. Soehnge and I.W. Hälbich, eds., Spec. Publ. Geol. Soc. S. Afr. 12, 131-148, 1983.

20 A.J. Tankard and D.K. Hobday, Sedimentation patterns in Early Paleozoic tensional failed arms: the Table Mountain Group of South Africa, Geol. Soc. Am. Progr. Abstr. 11, $526,1979$.

21 J. Gray, J.N. Theron and A.J. Boucot, Age of the Cedarberg Formation, South Africa, and early land plant evolution, Geol Mag. 123, 445-454, 1986.

22 I.C. Rust, The evolution of the Paleozoic Cape Basin, southern margin of Africa, in: The Ocean Basins and Margins, 1, A.E.M. Nairn and F.G. Stehli, eds., pp. 247-276, Plenum, New York, N.Y., 1973.

23 M.B. Edwards, Glacial environments, in: Sedimentary Environments and Facies, H.G. Reading, ed., pp. 416-438, Elsevier, Amsterdam, 1978.

24 L.R.M. Cocks and R.A. Fortey, New evidence on the South African Lower Palaeozoic: age and fossils reviewed, Geol. Mag. 123, 437-444, 1986.

25 W.B.N. Berry and A.J. Boucot, Correlation of the African Silurian rocks, Spec. Pap. Geol. Soc. Am. 147, 83 pp., 1973.

26 E.P. Plumstead, A new phytostratigraphical Devonian zone in southern Africa, which includes the first record of Zosterophyllum, Trans. Geol. Soc. S. Afr. 80, 267-277, 1977.

27 W.G. Chaloner, P.L. Forey, B.G. Gardiner, A.J. Hill and V.T. Young, Devonian fish and plants from the Bokkeveld
Series of South Africa, S. Afr. Mus. Ann. 81, 127-157, 1980.

28 A.J. Boucot, H.C. Brunton and J.N. Theron, Implications for the age of South African rocks in which Tropidoleptus (Brachiopoda) has been found, Geol. Mag. 120, 51-58, 1983.

29 B.G. Gardiner, New paleoniscid fish from the Witteberg Series of South Africa, Zool. J. Linn. Soc. 48, 423-452, 1969.

30 R.P. Stapleton, Carboniferous unconformity in southern Africa, Nature 268, 222-223, 1977.

31 R.P. Stapleton, Carbonised Devonian spores from South Africa, Pollen Spores 19, 427-440, 1977.

32 J.D.A. Zijderveld, AC demagnetization of rocks: analysis of results, in: Methods in Paleomagnetism, D.W. Collinson, S.K. Runcorn and K.M. Creer, eds., pp. 254-286, Elsevier, Amsterdam, 1967.

33 H.C. Halls, A least-squares method to find a remanence direction from converging great circles, Geophys. J. R. Astron. Soc. 45, 297-304, 1976.

34 J.L. Kirschvink, The least-square line and plane and the analysis of paleomagnetic data, Geophys. J. R. Astron. Soc. $62,699-718,1980$.

35 J.W. Graham, The stability and significance of magnetism in sedimentary rocks, J. Geophys. Res. 54, 131-167, 1949.

36 K.W.T. Graham, Paleomagnetic studies of some South African rocks, Ph.D. Thesis, 140 pp., University of Cape Town, Cape Town, 1961.

37 E. Irving, E. Tanczyk and J. Hastie, Catalogue of paleomagnetic directions and poles, third issue, Paleozoic results, Geomagnetic Series 5, 99 pp., Earth Physics Branch, Department of Energy. Mines and Resources, Ottawa, Ont., 1976.

38 R.A. Fisher, Dispersion on a sphere, Proc. R. Soc. London Ser. A 217, 295-305, 1953.

39 M.M. Ballard, R. Van der Voo and I.W. Hälbich, Remagnetizations in Late Permian and Early Triassic rocks from southern Africa and their implications for Pangea reconstructions, Earth Planet. Sci. Lett. 79, 412-418, 1986.

40 A. Brock, Paleomagnetism of Africa and Madagascar, Am. Geophys. Union., Geodyn. Ser. 2, 65-76, 1981.

41 R.G. Gordon, M.O. McWilliams and A. Cox, Pre-Tertiary velocities of the continents: a lower bound from paleomagnetic data, J. Geophys. Res. 84, 5480-5486, 1979.

42 J.C. Loock, J.M.J. Visser, South Africa, in: The Carboniferous of the World, C-M. Diaz, ed., IUGS Publ. 20, 451, Instituto Geol. Minero de España 1985. 